\title{
Isolation of Gas Vesicles from Methanosarcina barkeri
}

\author{
By DAVID B. ARCHER* AND NORMAN R. KING \\ ARC Food Research Institute, Colney Lane, Norwich NR4 7UA, UK
}

(Received 6 June 1983; revised 29 August 1983)

\begin{abstract}
A gas-vacuolate strain of Methanosarcina barkeri formed protoplasts in substrate-depleted cultures and gas vesicles were isolated from the protoplasts. Vacuolate protoplasts were separated from unvacuolate ones by flotation and the protoplast membrane was removed by Tween 20 , liberating the gas vesicles. The gas vesicles were purified by flotation after initial passage through a $0.45 \mu \mathrm{m}$ filter to remove contaminating material. Gas vesicle membranes were purified by isopycnic gradient centrifugation and were shown by electron microscopy to have a rib spacing of $4.8 \mathrm{~nm}$.
\end{abstract}

\section{INTRODUCTION}

Methanosarcina and Methanothrix are the only genera of methanogenic bacteria known to include gas-vacuolate strains (Zhilina, 1971; Zhilina \& Zavarzin, 1979; Mah \& Smith, 1981; Zinder et al., 1983). We recently described the isolation of another gas-vacuolate Methanosarcina (Archer \& King, 1983) and now report the isolation of gas vesicles from this organism.

The isolation of intact gas vesicles from non-methanogenic bacteria requires methods for breaking cells gently, to avoid collapsing the gas vesicles (Walsby, 1972). No gentle method has been described for the breakage of Methanosarcina barkeri, which normally grows as aggregates of cells enveloped by a shared heteropolysaccharide wall (Balch et al., 1979). Some strains of $M$. barkeri are known to lyse spontaneously in the stationary phase of a batch-fed culture (Smith \& Mah, 1978; Scherer \& Sahm, 1981) and it is reported here that strain FR-1 (Archer \& King, 1983 ) produces protoplasts spontaneously in osmotically suitable media. The protoplasts can then be lysed gently to enable the gas vesicles to be isolated free from other material.

\section{METHODS}

Organism.s and culture conditions. Methanosarcina harkeri strain FR-1 (DSM 2256) was grown in a yeast extract/mineral salts medium with methanol as the substrate (Archer \& King, 1983). Growth was estimated by measurement of methane production, and production of protoplasts from intact cells was followed by phasecontrast and fluorescence microscopy (Archer \& King, 1983).

Isolation of gas resicles. Gas vesicles were isolated from gas-vacuolate protoplasts of $\boldsymbol{M}$. barkeri strain FR-1. Protoplasts were centrifuged for $16 \mathrm{~h}$ in a swinging-bucket rotor at $300 \mathrm{~g}$ and $4{ }^{\circ} \mathrm{C}$. The maximum depth of liquid was $5.5 \mathrm{~cm}$, equivalent to a pressure of $165 \mathrm{kN} \mathrm{m}^{-2}$ (Walsby \& Buckland, 1969). The surface layer containing vacuolate protoplasts and free gas vesicles was removed, diluted tenfold in $20 \mathrm{~mm}$-Tris buffer $\mathrm{pH} 7 \cdot 5$, and the flotation was repeated. The protoplasts burst in the Tris buffer but usually resealed to form ghosts which enclosed the gas vesicles. This procedure was repeated several times. The washed preparation of vacuolate ghosts and free vesicles was resuspended in Tris buffer containing $1_{0}^{\circ}(w / v)$ Tween 20 (Polyoxyethylene sorbitan monolaurate, Sigma) and then filtered through $\mathbf{0 . 4 5} \mu \mathrm{m}$ pore size filters (Gelman Sciences Ltd., Northampton, UK). The filtrate was centrifuged at $300 \mathrm{~g}$ for $16 \mathrm{~h}$ and the surface layer removed. This gas vesicle preparation was washed several times by suspension in Tris buffer and flotation. No intact protoplasts or ghosts could then be seen by phasecontrast microscopy.

Isolation of gas resicle membranes. Gas vesicles were disrupted by sonication using an MSE ultrasonic disintegrator at $60 \mathrm{~W}$ for $10 \mathrm{~s}$. The disrupted gas vesicles were layered either on pre-formed linear Urografin

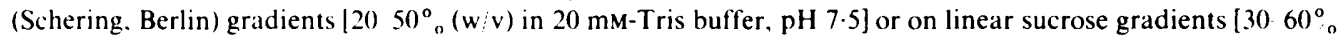


$(\mathrm{w} / \mathrm{v})$ in $20 \mathrm{mM}$-Tris buffer, $\mathrm{pH} 7 \cdot 5$ ]. The gradients were centrifuged in a swinging-bucket rotor $(150000 \mathrm{~g}$ for $16 \mathrm{~h}$ at $4{ }^{\circ} \mathrm{C}$ ). Visible bands were removed through the sides of the tubes. Densities were determined from measurements of refractive index. Material in the bands was sedimented after dilution in Tris buffer by centrifugation at $70000 \mathrm{~g}$ for $2 \mathrm{~h}$ at $4^{\circ} \mathrm{C}$, and washed in Tris buffer.

Electron microscopy. The techniques used for transmission electron microscopy were described by Archer \& King (1983). Preparations were mounted on carbon-coated grids and negatively stained with $2 \%(w / v)$ uranyl acetate and examined in an AEI 801 electron microscope.

Protein and sulphide assays. The amount of protein in cells and in gas vesicle preparations was determined by the method of Lowry. Soluble sulphide was estimated using a test kit (Model P70) from La Motte Chemical Products Co., Maryland, USA.

\section{RESULTS}

\section{Protoplast formation}

Methanosarcina barkeri strain FR-1 grew in aggregates of cells but in the stationary phase of growth, when methane production had ceased, individual osmotically sensitive and spherical bodies, presumed to be protoplasts, were released. No intact cells were seen in cultures containing protoplasts. The protoplasts were readily lysed in water and non-ionic detergents such as Tween 20 and Triton X-100, in contrast to intact cells which retained their integrity. Other authors have reported lysis of $M$. barkeri in the stationary phase and lysis may be dependent on the concentration of sulphide in the medium (Smith \& Mah, 1978; Scherer \& Sahm, 1981). There may be a number of factors involved in the protoplast formation or lysis of strain FR-1 but merely varying the sulphide $\left(\mathrm{as}^{\mathrm{Na}} \mathrm{Na}_{2} \mathrm{~S}\right)$ concentration had an obvious effect on the protoplast formation and methane yields of strain FR-1 (Fig. 1). Maximum methane yields from strain FR-1 occurred with the addition of 0.4-1.8 mM-sulphide but protoplasts were only produced when 1.2-2.4 mM-sulphide was added. Methanogenesis by strain FR-1 was inhibited at added sulphide concentrations above $2.4 \mathrm{~mm}$, and cell lysis, without protoplast formation, occurred at such high levels. These values for the growth dependence of $M$. barkeri upon added sulphide concentrations are in accord with other published values (Mountfort \& Asher 1979; Scherer \& Sahm, 1981). Estimates of the soluble sulphide present were also made and it was found that most methane was produced with free sulphide concentrations up to $0.14 \mathrm{mM}$, protoplasts being formed when the free sulphide concentration was between 0.08 and $0.28 \mathrm{mM}$. Protoplast formation of strain FR-1 has also been observed in the stationary phase of cultures grown on acetate or $\mathrm{H}_{2}+\mathrm{CO}_{2}$ as the sole carbon and energy sources instead of methanol. Cultures of strain FR-1 consisted entirely of protoplasts approximately 2 weeks after inoculation and work is in progress to determine the actual requirements for protoplast formation. The

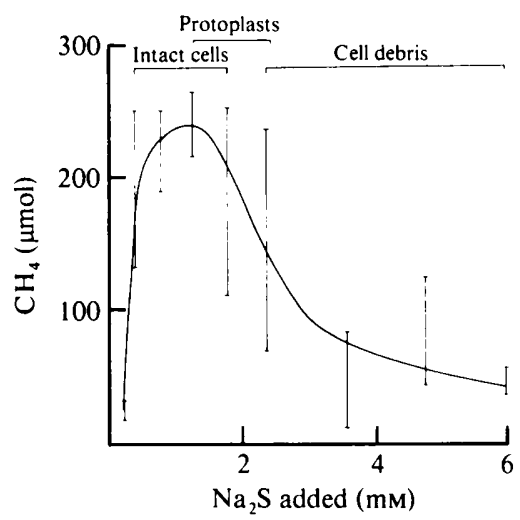

Fig. 1. Methanogenesis by Methanosarcina barkeri strain FR-1 in the presence of different amounts of sulphide. The amounts of methane plotted were the maximum recorded from $4.5 \mathrm{ml}$ cultures, $2-3$ weeks after inoculation. The ranges given (indicated by bars) are from triplicate experiments. The presence in the cultures of intact cells, protoplasts or cell debris is indicated. 

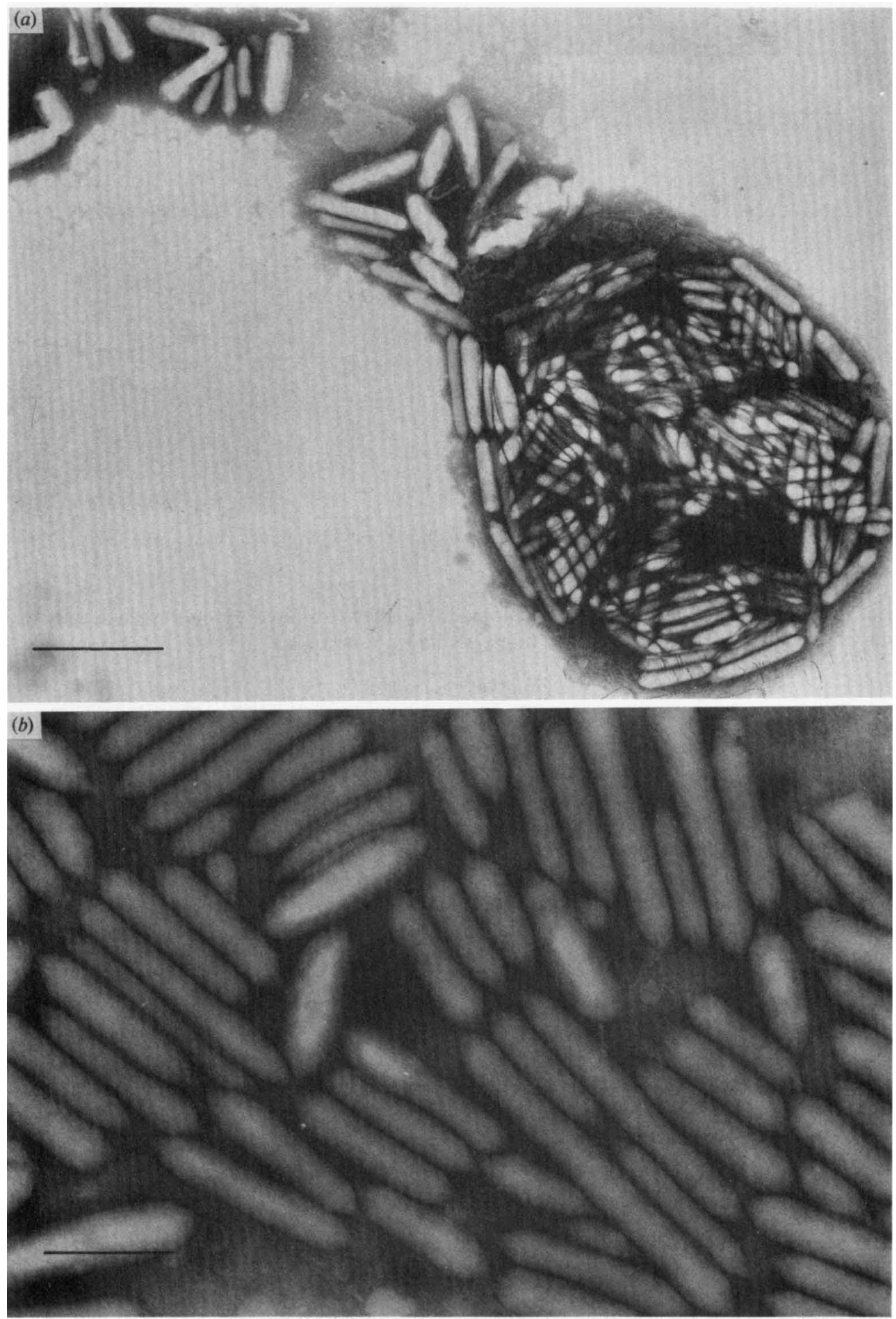

Fig. 2.(a) Release of gas vesicles from a vacuolate protoplast, stained with uranyl acetate. The bar marker represents $500 \mathrm{~nm}$. (b) Gas vesicle preparation, stained with uranyl acetate. The bar marker represents $200 \mathrm{~nm}$. 


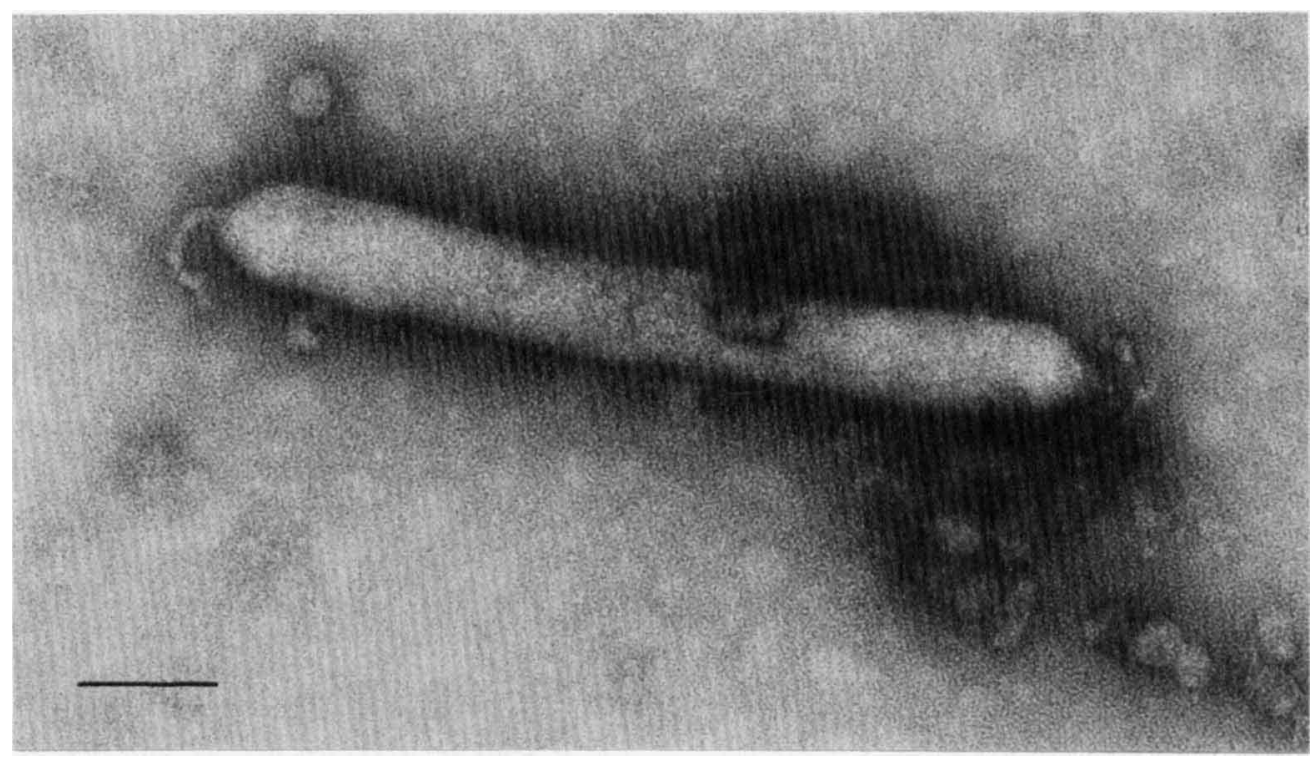

Fig. 3. Isolated gas vesicle showing terminal stalk, stained with uranyl acetate. The bar marker represents $100 \mathrm{~nm}$.

viability of the protoplasts was not examined, but they exhibited epifluorescence due to the soluble cofactor $\mathrm{F}_{420}$, an indication that lysis had not occurred.

\section{Isolation of gas vesicles}

Protoplasts were lysed by suspension in $20 \mathrm{~mm}$-Tris buffer (pH 7.5) and lost their epifluorescence property but persisted mainly as ghosts, retaining the gas vesicles, judged by phase-contrast microscopy. Intact gas vesicles were released from the ghosts by addition of Tween $20(1.0 \%, \mathrm{w} / \mathrm{v})$ or sodium deoxycholate $(1.0 \%, \mathrm{w} / \mathrm{v})$, but Triton X-100 $(1.0 \%, \mathrm{w} / \mathrm{v})$ or SDS $(1.0 \%, \mathrm{w} / \mathrm{v})$ collapsed the gas vesicles. Release of gas vesicles from a protoplast is shown in Fig. $2(a)$, and a preparation of gas vesicles is shown in Fig. $2(b)$. The average diameter of gas vesicles within cells, measured from electron micrographs of thin sections (Archer \& King, 1983) was $41.9 \pm 4.1 \mathrm{~nm}$ (mean $\pm \mathrm{SD}$ ), but isolated gas vesicles were often distorted and had an apparent average diameter of $63.2 \pm 9.7 \mathrm{~nm}$. The length of most of the isolated vesicles varied from 150 to $500 \mathrm{~nm}$. Occasionally a stalk was seen at the gas vesicle end (Fig. 3).

\section{Isolation of gas vesicle membranes}

Intact gas vesicles were collapsed instantly by sonication. One band was seen in urografin density gradients; this had an apparent density of $1.16 \mathrm{~g} \mathrm{~cm}^{-3}$ and was found by electron microscopy to contain gas vesicle membranes (Fig. 4). Occasionally, a less dense band was observed and this was shown by electron microscopy not to contain gas vesicle membranes, but it did contain membrane fragments presumed to be from the protoplast plasma membrane. The lighter band was never observed in samples that had been resuspended in Tris buffer containing $1 \%(w / v)$ SDS, but the position of the gas vesicle membrane band in the density gradients was not affected by this treatment. The gas vesicle membranes did not band on sucrose density gradients. They were sedimented through $60 \%(\mathrm{w} / \mathrm{v})$ sucrose indicating a density greater than $1 \cdot 29 \mathrm{~g} \mathrm{~cm}^{-3}$.

The gas vesicle membranes (Fig. 4) had a rib spacing of $4.8 \pm 0.7 \mathrm{~nm}$. Approximately $1 \%$ of the cell protein was recovered in the gas vesicle membrane band but as the losses of the gas vesicle membrane during the isolation procedure could not be estimated the amount of gas vesicle membrane protein in a cell was probably more than this. Gas vesicle membranes were not readily solubilized in boiling SDS and most of the protein applied to polyacrylamide gels 


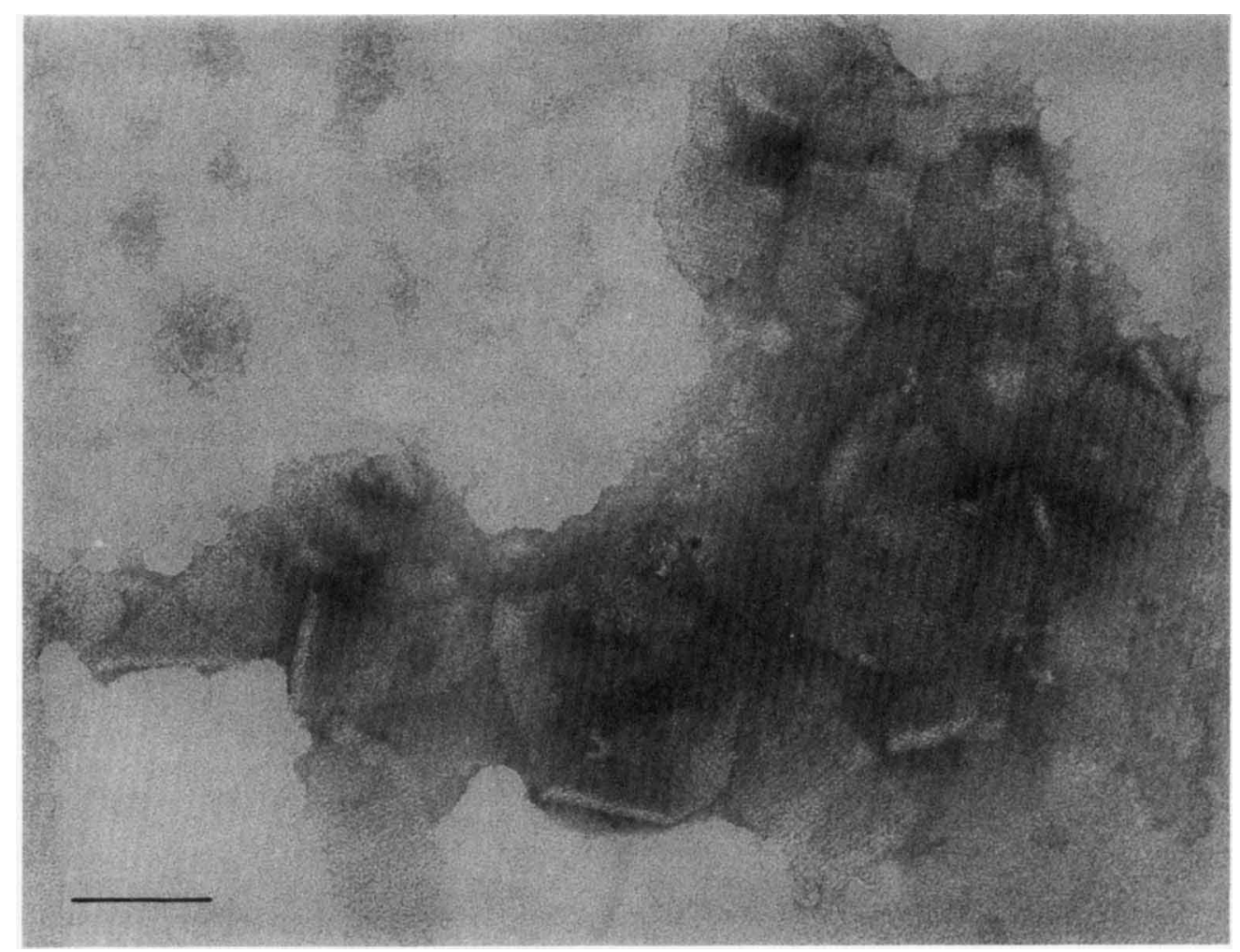

Fig. 4. Gas vesicle membranes, stained with uranyl acetate. The bar marker represents $100 \mathrm{~nm}$.

(Laemmli \& Favre, 1973) did not enter the gel. Some very faintly-stained bands were sometimes seen but were probably due to contaminating material and not gas vesicle membrane protein.

\section{DISCUSSION}

Protoplasts of two other methanogenic species have been described (Sprott et al., 1979; Jarrell et al., 1982), but although lysis of Methanosarcina barkeri is known to occur (Smith \& Mah, 1978) protoplasts have not previously been reported. Lysis of Methanobacterium bryantii occurred instead of protoplasting unless the medium was osmotically suited to the protoplasts (Jarrell et al., 1982). The protoplasts of $M$. barkeri were stable in the medium used here but some ghosts were normally present; alterations can be made to the growth medium to improve stability of the protoplasts (R. P. Davies \& D. B. Archer, unpublished information). The protoplasts of $\boldsymbol{M}$. barkeri were osmotically sensitive and burst in water but usually resealed to form membranebound ghosts, retaining the gas vesicles. Detergents disrupted the protoplasts, in contrast to their effect on cells. This procedure has been used previously with other organisms (Walsby \& Armstrong, 1979).

Many different bacterial species are known to be gas-vacuolate (Walsby, 1981 $a, b$ ). The dimensions and rib spacing of the isolated $M$. barkeri gas vesicles are similar to the reported values for gas vesicles isolated from a variety of phylogenetically unrelated species (Walsby, 1972). Stalks have also been seen on vesicles from other species (Walsby, 1972). Some halobacteria, which like methanogens are classified as archaebacteria, are known to contain gas vacuoles (Houwink, 1956: Stoeckenius \& Kunau, 1968).

The density of the gas vesicle membranes from $M$. barkeri was estimated to be $1.16 \mathrm{~g} \mathrm{~cm}^{-3}$ in urografin but greater than $1.29 \mathrm{~g} \mathrm{~cm}^{-3}$ in sucrose. A density of about $1.3 \mathrm{~g} \mathrm{~cm}^{-3}$ is expected for gas vesicle membranes which are comprised solely of protein (Walsby, 1972). Apart from the gas 
vesicle membranes, very little material which may have altered the density was detected by electron microscopy and the density in urografin did not alter with prior suspension in $1 \%(\mathrm{w} / \mathrm{v})$ SDS, which dissolves the protoplast membrane very effectively. The apparently low density in urografin is unlikely to reflect the true density of the gas vesicle membrane and a density of about $1.3 \mathrm{~g} \mathrm{~cm}^{-3}$ is considered probable. The gas vesicles were collapsed by the detergents Triton X-100 and SDS but not by Tween 20 or sodium deoxycholate. Although the M. barkeri gas vesicles were collapsed by SDS the gas vesicle membrane was not solubilized. Gas vesicle membranes from a number of species are resistant to solubilization in SDS (Walsby, 1972, 1978) although some solubilization of freshly prepared gas vesicles from Nostoc muscorum (Armstrong et al., 1983) and Anabaena flos-aquae (Walker \& Walsby, 1983) has been achieved. In these cases the gas vesicle membranes comprised only one protein, as is thought to be the case with other gas vesicles (Walsby, 1972, 1978; Walker \& Walsby, 1983) of approximate molecular weight 20000 , and although it was detected in solubilized whole cells of vacuolate forms it was not present in unvacuolate cells.

We are grateful to R. A. Makins and S. H. Jones for technical assistance.

\section{REFERENCES}

ARCher, D. B. \& KING, N. R. (1983). A novel ultrastructural feature of a gas-vacuolated Methanosarcina. FEMS Microbiology Letters 16, 217-223.

Armstrong, R. E., Hayes, P. K. \& Walsby A. E. (1983). Gas vacuole formation in hormogonia of Nostoc muscorum. Journal of General Microbiology 129, 263-270

Balch, W. E., Fox, G. E., Magrum, L. J., Woese, C. R. \& Wolfe, R. S. (1979). Methanogens: reevaluation of a unique biological group. Microbiological Review's 43, 260-296.

Houwink, A. L. (1956). Flagella, gas vacuoles and cell wall structure in Halobacterium halobium: an electron microscopic study. Journal of General Microbiology $15,146-150$.

Jarrell, K. F., Colvin, J. R. \& Sprott, G. D. (1982). Spontaneous protoplast formation in Methanobacterium bryantii. Journal of Bacteriology 149, 346-353.

Laemmli, U. K. \& FaVRE, M. (1973). Maturation of the head of bacteriophage T4. I. DNA packaging events. Journal of Molecular Biology 80, 575599.

MAH, R. A. \& SMITH, M. R. (1981). The methanogenic bacteria. In The Prokaryotes, pp. 948-977. Edited by M. P. Starr, H. Stolp, H. G. Truper, A. Balows \& H. G. Schlegel. Berlin: Springer-Verlag.

MOUNTFORT, D. O. \& ASHER, R. A. (1979). Effect of inorganic sulphide on the growth of Methanosarcina harkeri strain DM. Applied and Entironmental Microbiology 37, 670-675.

SCherer, P. \& SaYM, H. (1981). Influence of sulphurcontaining compounds on the growth of Methanosarcina barkeri in a defined medium. European Journal of Microhiology and Biotechnolog. 12, $28-35$.

Smith, M. R. \& MAH, R. A. (1978). Growth and methanogenesis by Methanosarcina strain 227 on acetate and methanol. Applied and Environmental Microhiology 36, 870-879.

Sprott, G. C., Colvin, J. R. \& McKellar, R. C. (1979). Spheroplasts of Methanospirillum hungatii formed upon treatment with dithiothreitol. Canadian Journal of Microbiology 25, 730-738.
Stoeckenius, W. \& Kunau, W. H. (1968). Further characterization of particulate fractions from lysed cell envelopes of Halobacterium halobium and isolation of gas vacuole membranes. Journal of Cell Biology 38, 336-357.

Walker, J. E. \& Walsby, A. E. (1983). Molecular weight of gas-vesicle protein from the planktonic cyanobacterium Anabaena flos-aquae and implications for structure of the vesicle. Biochemical Journal 209, 809-815.

WALSBY, A. E. (1972). Structure and function of gas vacuoles. Bacteriological Reviews 36, 1-32.

WalsBy, A. E. (1978). The gas vesicles of aquatic prokaryotes. Symposia of the Society for General Microbiology 28, 327-357.

WalsBY, A. E. (1981a). Cyanobacteria: planktonic gas-vacuolate forms. In The Prokaryotes, pp. 224235. Edited by M. P. Starr, H. Stolp, H. G. Truper, A. Balows \& H. G. Schlegel. Berlin: SpringerVerlag.

WALSBY, A. E. (1981 b). Gas-vacuolate bacteria (apart from cyanobacteria). In The Prokaryotes, pp. 441447. Edited by M. P. Starr, H. Stolp, H. G. Truper, A. Balows \& H. G. Schlegel. Berlin: SpringerVerlag.

Walsby, A. E. \& ARMSTrong, R. E. (1979). Average thickness of the gas vesicle wall. Journal of Molecular Biology 129, 279-285.

Walsby, A. E. \& BuCKLAND, B. (1969). Isolation and purification of intact gas vesicles from a blue-green alga. Nature, London 224, 716-717.

Zhilina, T. N. (1971). The fine structure of Methanosarcina. Microbiology (English translation of Mikrobiologịa) 40, 674 680 .

Zhilina, T. N. \& Zavarzin, G. A. (1979). Comparative cytology of methanosarcinae and description of Methanosarcina racuolata sp. nova. Microbiology (English translation of Mikrohiologiya) 48, 223-228.

ZiNder, S., Cardwell, S. \& ANGUish, T. (1983). Ecology of methanogens in a thermophilic anaerobic digester. Abstracts of the Annual Meeting of the American Society for Microbiology, p. 146. 